Revista Brasil. Bot., V.32, n.2, p.319-327, abr.-jun. 2009

\title{
Anatomical and developmental aspects of leaf galls induced by Schizomyia macrocapillata Maia (Diptera: Cecidomyiidae) on Bauhinia brevipes Vogel (Fabaceae)
}

\author{
CAMILA EMILIANE MENDES DE SÁ ${ }^{1}$, FERNANDO A. O. SILVEIRA ${ }^{1}$, JEAN C. SANTOS ${ }^{1}$, \\ ROSY MARY DOS SANTOS ISAIAS ${ }^{2}$ and G. WILSON FERNANDES ${ }^{1,3}$
}

(received: May 24, 2007; accepted: March 11, 2009)

\begin{abstract}
Anatomical and developmental aspects of leaf galls induced by Schizomyia macrocapillata Maia (Diptera: Cecidomyiidae) on Bauhinia brevipes Vogel (Fabaceae)). Samples of healthy leaves and galls induced by Schizomyia macrocapillata Maia on Bauhinia brevipes Vogel were submitted to routine techniques to investigate gall anatomy and development. Pouch galls are induced on the abaxial surface of unfolded immature leaves, and become spheroid with long reddish hairs covering their external surface. Galls occur isolated or coalesce when in larger numbers. Gall development was divided into six phases: 1) initiation; 2) tissue re-arrangement; 3) tissue differentiation; 4) maturation; 5) growth phase; and 6) dehiscence. This last phase corresponds to gall senescence, which takes place just after the larva exits the chamber to pupate. An important developmental phase of tissue reorientation was recorded after the initiation phase. The presence of hyphae close to the covering layer characterizes this gall as an ambrosia gall and the feeding mode of the gall migde is discussed. Few hyphae were found during the first developmental phases and fungi may play an important role during gall morphogenesis. Neoformed trichomes may provide not only photoprotection but also protection against natural enemies and water loss. The neoformation of phloematic bundles suggests host manipulation and indicates the establishment of a deviating sink.
\end{abstract}

Key words - ambrosia gall, gall anatomy, gall midge, mycetophagy, ontogenesis

RESUMO - (Anatomia e desenvolvimento de galhas induzidas por Schizomyia macrocapillata Maia (Diptera: Cecidomyiidae) em folhas de Bauhinia brevipes Vogel (Fabaceae)). Amostras de folhas sadias e de galhas induzidas por Schizomyia macrocapillata Maia em folhas de Bauhinia brevipes Vogel foram submetidas a técnicas usuais para investigações anatômicas e desenvolvimento da galha. As galhas são induzidas na face abaxial de folhas imaturas não expandidas e assumem formato esférico, com longos tricomas avermelhados recobrindo sua superfície externa. Na lâmina foliar podem ocorrer galhas isoladas ou agrupadas em grandes números. O desenvolvimento da galha foi dividido em seis fases: 1) indução; 2) rearranjo tecidual; 3) diferenciação; 4) maturação; 5) crescimento; e 6) deiscência. Esta última fase corresponde à senescência que ocorre logo após a saída do indutor da câmara larval para pupar. Uma fase importante de reorientação tecidual foi registrada após a fase de indução. A presença de hifas de fungos circundando o revestimento da câmara caracteriza a galha como de ambrosia e o modo de alimentação do indutor é discutido. Poucas hifas foram encontradas nas fases iniciais do desenvolvimento e o fungo parece ter um papel importante na morfogênese da galha. Tricomas neoformados possivelmente conferem fotoproteção, além de proteção contra inimigos naturais e perda de água. A neoformação de feixes floemáticos sugere a manipulação do metabolismo do hospedeiro e indicam o estabelecimento de um dreno.

Palavras-chave - anatomia de galha, galha de ambrosia, micetofagia, ontogênese

\section{Introduction}

Insect galls may be induced on all plant organs, from apical roots to apical shoots, on vegetative and reproductive organs of virtually all plant species. Anatomical studies on leaf galls induced by the Cecidomyiidae family (Diptera) indicate profound modifications at the cell and

1. Universidade Federal de Minas Gerais/DBG, ICB/Ecologia Evolutiva \& Biodiversidade, Caixa Postal 486, 31270-901 Belo Horizonte, MG, Brazil.

2. Universidade Federal de Minas Gerais, ICB/Departamento de Botânica, Caixa Postal 486, 31270-901 Belo Horizonte, MG, Brazil.

3._Corresponding author: gwilson@icb.ufmg.br tissue levels (Bronner 1992, Rohfritsch 1992, Kraus et al.2003). Conspicuous palisade parenchyma proliferation and cell hypertrophy were reported in Piptadenia gonoacantha (Mart.) J. F. Macbr. (Fabaceae) (Arduin \& Kraus 1995) whereas in galls induced on Guarea macrophylla subsp. tuberculata (Vell.) T. D. Penn. (Meliaceae) the spongy parenchyma cells also divide and become rounded with small intercellular spaces (Kraus et al. 1996). Regarding the vascular system, gall formation on the leaves of Baccharis concinna G. M. Barroso (Asteraceae) causes alterations in periciclic fibers, which loose their ordinary secondary walls noticed in healthy leaves (Arduin \& Kraus 2001). 
The larvae of the galling insects generally feed on a nutritive tissue that internally surrounds the gall chamber (Rohfritsch 1992). Bronner (1992) outlines that in cecidomyiid galls, nutritive cells are never destroyed by the larva, while extensive development of vascular tissues is observed. Nevertheless, some gall midges are associated to fungi whose mycelia line the larval chamber on which the larva feed upon (Meyer 1987, Gagné 1989, Rohfritsch 1992). In this case, the nutritive tissue is usually absent and the gall is denominated an ambrosia gall (Rohfritsch 2008). This type of gall is rarely reported in the tropics and is assumed to be a type of mutualism as larval survival depends on the adult female collecting the fungus and depositing it along with the eggs in the attacked organ of the host plant (Rohfritsch 2008). Although many progresses on the anatomy of Cynipidae- and Cecidomyiidae-induced galls has been achieved (Bronner 1992, Rohfritsch 1992, Brooks \& Shorthouse 1998, Rohfritsch 2008), to date, only one study on the anatomy of an ambrosia leaf gall has been conducted in the Brazilian flora (Arduin \& Kraus 2001). Moreover, to our knowledge no Neotropical study has reported on ambrosia gall development from egg deposition to gall maturation.

The ambrosia galls of the cecidomyiids are induced by Asphondyliini and Lasiopterini (Rohfritsch 2008) belonging to species of Asphondylia, Lasioptera, Kiefferia and Schizomyia (Meyer 1987, Bronner 1992, Gagné 1994). The gut of these species shows features of the ancestral mycetophagous habit, being similar to that of mycetophagous non-galling Cecidomyiidae (Rohfritsch 2008). Schizomyia species are worldwide distributed; their larvae are very active, generally red or orange, and pupate in the ground (Gagné 1989, Rohfritsch 2008). Their galls are generally induced on leaves of the host plants (Fontes et al. 1994, Maia \& Fernandes 2005), but may also be found on stems, flowers, and fruits (Meyer 1987, Rohfritsch 2008).

The gall migde Schizomyia macrocapillata Maia (Cecidomyiidae: Asphondyliini) induces galls on leaves of Bauhinia brevipes Vogel (Fabaceae) (Maia \& Fernandes 2005). Oviposition takes place on the onset of the rainy season when leaf-flush occurs simultaneously and leaves are still unfolded. Although during the last 15 years several ecological features of the interaction between $S$. macrocapillata and its host plant have been studied (e.g. Cornelissen et al. 1997, Fernandes 1998, Cornelissen \& Fernandes 2001, Santos et al. 2008), no information on the anatomical and ontogenetical aspects of the gall have been provided. Therefore, the goal of this study was to report on the anatomical and developmental aspects of the ambrosia leaf gall induced by S. macrocapillata on $B$. brevipes.

\section{Material and methods}

Study area and species - This study was performed at the Estação Ecológica de Pirapitinga (EEP) in Três Marias, Minas Gerais, Southeastern Brazil. The EEP is a 1.100 ha man-made island, built in 1965 at the Três Marias reservoir $\left(18^{\circ} 23^{\prime} \mathrm{S}, 45^{\circ} 20^{\prime} \mathrm{W}\right)$ at an altitude of $560 \mathrm{~m}$ a.s.l. (Azevedo et al. 1987). The average annual temperature varies from 21 to $25^{\circ} \mathrm{C}$ and the average annual precipitation is $1.200 \mathrm{~mm}$, with rainy summers and dry winters. The vegetation is primarily Cerrado (Brazilian savanna) with sandy, shallow and nutrient-poor soils, with high aluminum saturation (Gonçalves-Alvim \& Fernandes 2001).

Bauhinia brevipes is a deciduous shrub, abundant at the Cerrado vegetation, but also found at the Caatinga. It grows up to $3 \mathrm{~m}$ high and its geographic distribution ranges from Bolivia to Brazil (Vaz \& Tozzi 2003). Blooming takes place between June and September and fruiting peak occurs between September and October, when the species is leafless. Leaf sprouting starts simultaneously at the onset of the rainy season in October and lasts until mid rainy season (Cornelissen \& Fernandes 2001). Galling insect attack and gall induction are observed in October (Fernandes 1998, Santos et al. 2008). Schizomyia macrocapillata induces spherical galls with a single chamber, prominent on the adaxial leaf surface. Galls are single-chambered with a single larva, and are covered by whitish hairs that become reddish as galls mature (Maia \& Fernandes 2005). It is the most abundant gall occurring on B. brevipes (Santos et al. 2008 and references therein).

Sampling - Samples of healthy leaves and leaves galled by $S$. macrocapillata on six developmental stages were collected around the canopy of several $B$. brevipes individuals. The youngest gall developmental stage was determined based on the smallest diameter, observed as a small, white-bulging leaf blade. Galls were dissected under a stereomicroscope using razor blades for separating damaged or parasitized galls and to remove $S$. macrocapillata larvae. Leaves and galls were fixed, numbered and taken to the laboratory for anatomical analyses.

Anatomical and ontogenetical analyses - For structural analysis, samples were fixed in FAA (formalin 37\%, acetic acid and ethanol 50\%, 1:1:18, $\mathrm{v} \mathrm{v}^{-1}$ ) (Johansen 1940), stocked in ethanol $70 \%$ and dehydrated in n-buthyl series, embedded in Paraplast ${ }^{\circledR}$ (Kraus \& Arduin, 1997). Samples were sectioned $(12 \mu \mathrm{m})$ in a rotative microtome (Reichert Jung model 2040), and staining was performed with safranin and astra blue $\left(2: 8, \mathrm{v} \mathrm{v}^{-1}\right)$ (Kraus \& Arduin 1997). Phenolic contents were detected by intense safranin content coloration and confirmed with ferric chloride test (Johansen 1940). Slides were mounted in Entellan ${ }^{\circledR}$.

The ontogenetical stages were determined in two steps. During the first step, the galls were measured with a caliper and separated into five size classes. The second step consisted of the anatomical analysis followed by the reorganization of the gall stages according to Rohfritsch (1992). 


\section{Results}

Healthy leaves - Leaves of B. brevipes are two-part deeply cleft (figure 1), dorsiventral (figure 2), amphistomatic and hairy. Epidermis is uniseriated, with round cells in transverse section at the adaxial surface, and papilose and smaller at the abaxial surface (figure 2), features maintained over the midrib (figure 3). Paracitic stomata are distributed at the abaxial surface (figure 4), and uniformly distributed all over leaf lamina. Glandular trichomes are exclusively present at the abaxial surface (figure 5). Non-glandular, pluricellular and uniseriated trichomes (figure 6) occur over the bundles on both leaf surfaces.
Primary and secondary xylem and phloem constitute the main vascular system, organized in a group surrounded by 3-6 layers of periciclic fibers and a parenchymatic endodermis (figure 3). The secondary veins were constituted just of primary vascular tissues with collateral arrangement surrounded by an endodermis with vascular extensions either to adaxial or abaxial surfaces (figure 2).

Galls induced by Schizomyia macrocapillata - Galls were spheroid, with long reddish hairs covering the external surface, occurring either isolated (figure 7) or in coalescence (grouped) (figure 8). Gall induction occurs on the abaxial surface of young leaves when leaf laminas
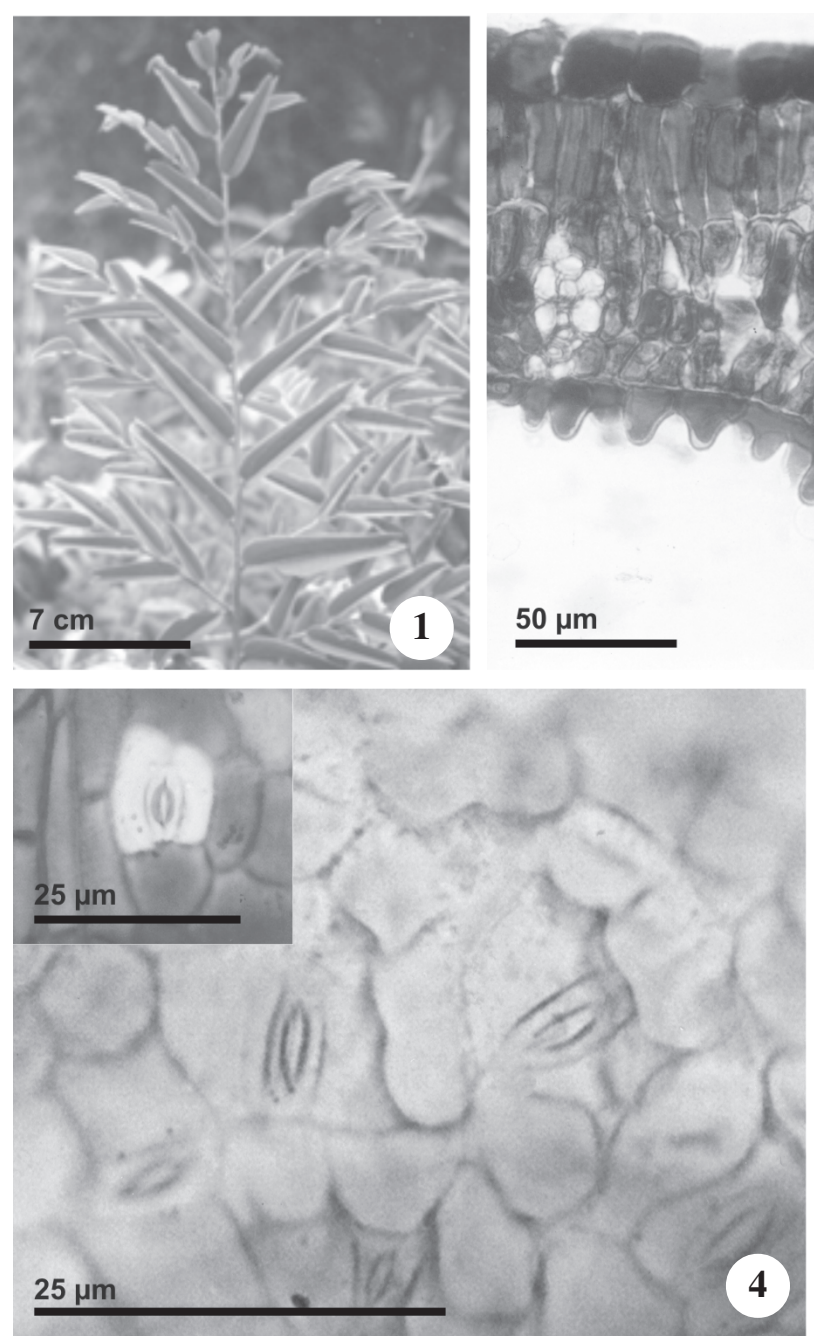
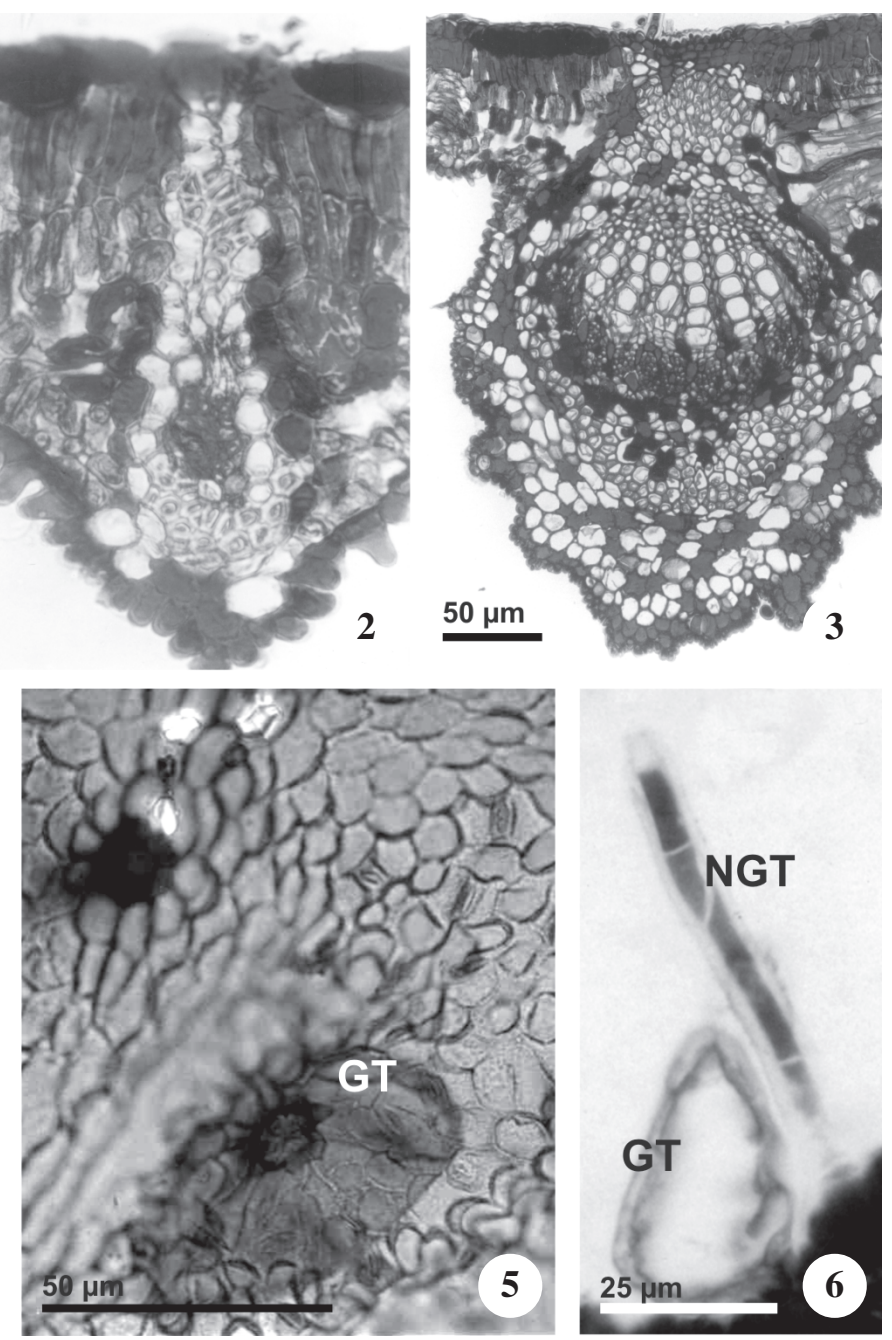

Figures 1-6. Bauhinia brevipes 1. General aspect of healthy shoots. 2-3. Leaf lamina in tranverse sections. 2. Uniseriated epidermis, dorsiventral mesophyll and minor veins. 3. Midrib prominent to the abaxial surface. Colateral arrangement of vascular tissues. 4-5. Frontal view of epidermis. 4. Abaxial surface with scattered stomata. Paracitic stomata of adaxial surface in detail. 5. Detail of a glandular trichome and prismatic crystals. 6. Glandular and nonglandular trichomes in transverse section. $(\mathrm{GT}=$ glandular trichome; $\mathrm{NGT}=$ non-glandular trichome). 
are still unfolded. The first gall visual effect is the invagination of the abaxial surface towards the adaxial side of the leaf lamina, ranging from 0.6 to $1.4 \mathrm{~mm}$. Later on, a round structure is projected to the adaxial side of the leaf lamina, reaching $3.3 \mathrm{~mm}$ of diameter and $6.26 \mathrm{~mm}$ from the abaxial leaf epidermis to adaxial epidermis.

Gall development was divided into six phases: 1) initiation; 2) tissue re-arrangement; 3) tissue differentiation; 4) maturation; 5) growth phase; and 6) dehiscence. This last phase corresponds to the senescence one, which took place just after the larvae leave the chamber to pupate. In this last phase, the larva drills the gall wall to pupate among the gall trichomes or drop on the Cerrado floor to pupate a few millimeters in the soil (G.W.F., personal observations).

All gall phases are characterized by round structures on the adaxial epidermis with neoformed glandular and non-glandular trichomes, absence of periciclic fibers around the vascular bundles, and larval chamber surrounded by epidermal cells which were nominated heretofore as covering layer. Gall walls from phase 3 on (tissue differentiation) had nearly 13 layers of newly differentiated parenchyma. Phenolic compounds were present in non-glandular trichomes, in the adaxial and abaxial surface, in cell layers along gall wall, and dispersed in cells of the basal region of the gall.

Phase 1 - Initiation - Leaf lamina was barely thickened, but hypertrophied in the site of larval feeding. This site was characterized by a small invagination from the abaxial to the adaxial side of the lamina. Adaxial epidermal cells were not as globose as in healthy leaf lamina and presented neoformed non-glandular trichomes (figure 9); the palisade and spongy parenchyma did not suffer alterations. The abaxial epidermal cells and the cells of the mesophyll adjacent to the site of gall induction were necrotic (figure 10) and filled with phenolic compounds around the invagination. Few hyphae occurred close to gall inductor.

Phase 2 - Tissue re-arrangement - This phase was characterized by the anomalous organization of leaf tissues in relation to those of healthy leaves (figure 11). Cells in the adaxial epidermis were uniseriated, ovoid with glandular and non-glandular trichomes. Cells on abaxial epidermis were neoplasic, with scarce non-glandular and glandular trichomes. The vascular bundles were slightly disorganized by the division of xylem and phloem parenchyma cells. A few hyphae were found next to abaxial epidermis invagination. Lesions and necrosis of the epidermal cells were common. Parenchyma cells in palisade position were round and interspersed to intercellular spaces.

Phase 3 - Tissue differentiation - The main feature of this phase was the long and narrow parenchyma cells aligned in anticlinal rows (figure 12), with inconspicuous intercellular spaces. The abaxial epidermis of leaf lamina is continuous inside the invagination and glandular and non-glandular trichomes persisted (figure 12). In the ostiole, some necrotic cells and hyphae were observed. Vascular bundles nearby remained unaltered except by the absence of periciclic fibers.

Phase 4 - Maturation - From this phase on, gall was globose and projected to the adaxial surface (figure 13). The region of connection of the gall to leaf lamina was thickened. Gall protuberances invaginate within the gall chamber filling it almost completely (figure 13). The ostiole was maintained and papilose cells and trichomes were observed nearby. The cells of the covering layer were smaller than those of gall wall (figure 14), and present phenolic contents; rare stomata were observed. The parenchyma around covering layer cells presented calcium oxalate crystals (figures 13 and 14). Neoformed vascular bundles were present all over the structure and were predominantly phloematic. Glandular and nonglandular trichomes were present in both gall surfaces, but more numerous on the adaxial surface (figure 13). Hyphae were found next to the covering layer.

Phase 5 - Growth phase - Gall increased in size as a result of hyperplasia and cell hypertrophy. This phase is marked by the changing in gall shape, which varied from globose to elliptical, with its major portion projected to the adaxial surface. The gall chamber was enlarged, with no protuberances inside it (figure 15). Hyphae were denser and concentrated next to the ostiole (figure 16). Nonglandular and glandular trichomes (figure 17) covered gall surface and were more spaced than in previous phases. Cells of the covering layer were reduced in relation to the other cells of gall wall, gall parenchyma is homogeneous with dense phenolic contents concentrated next to the adaxial surface (figure 18). In median cell layers, vascular bundles and less dense phenolic contents are observed. Nevertheless, these features were not homogeneous all around the chamber. The regions of connection of the gall to non galled leaf lamina have hypertrophied parenchyma cells and several vascular bundles.

Phase 6 - Dehiscence - This phase was structurally similar to the previous stages. However, some cells of the covering layers were necrotic (figure 19) while others present phenolic contents (figure 20). 

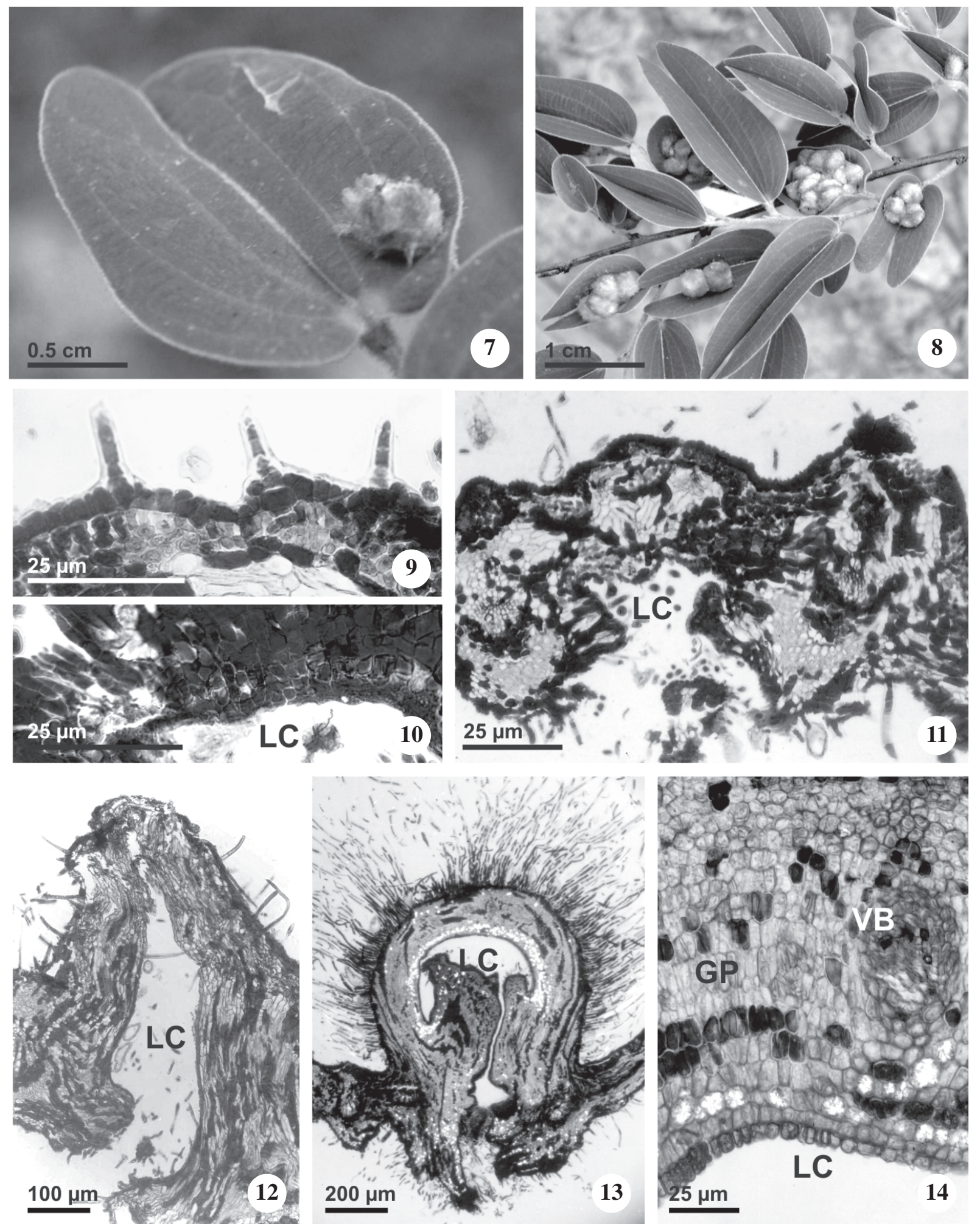

Figures 7-14. Schyzomyia macrocapillata gall in Bauhinia brevipes. 7. Isolated gall on leaflet adaxial surface. 8. Grouped galls. 9-14. Tranverse sections. 9-10. Phase 1: Initiation. 9. Adaxial epidermis with non-glandular trichomes. 10. Necrotic epidermal cells in gall induction site. 11. Phase 2: general aspect of tissue re-arrangement. 12. Phase 3: general aspect of cell elongation. 13. Phase 4: Maturation. General aspect evidencing invaginations towards gall chamber, trichomes around gall and gall ostiole, and calcium oxalate crystals. 14. Detail of covering layer cells, calcium oxalate crystals and parenchyma cells of the gall wall. $(\mathrm{GP}=$ gall parenchyma; $\mathrm{LC}=$ larval chamber; $\mathrm{VB}=$ vascular bundle). 

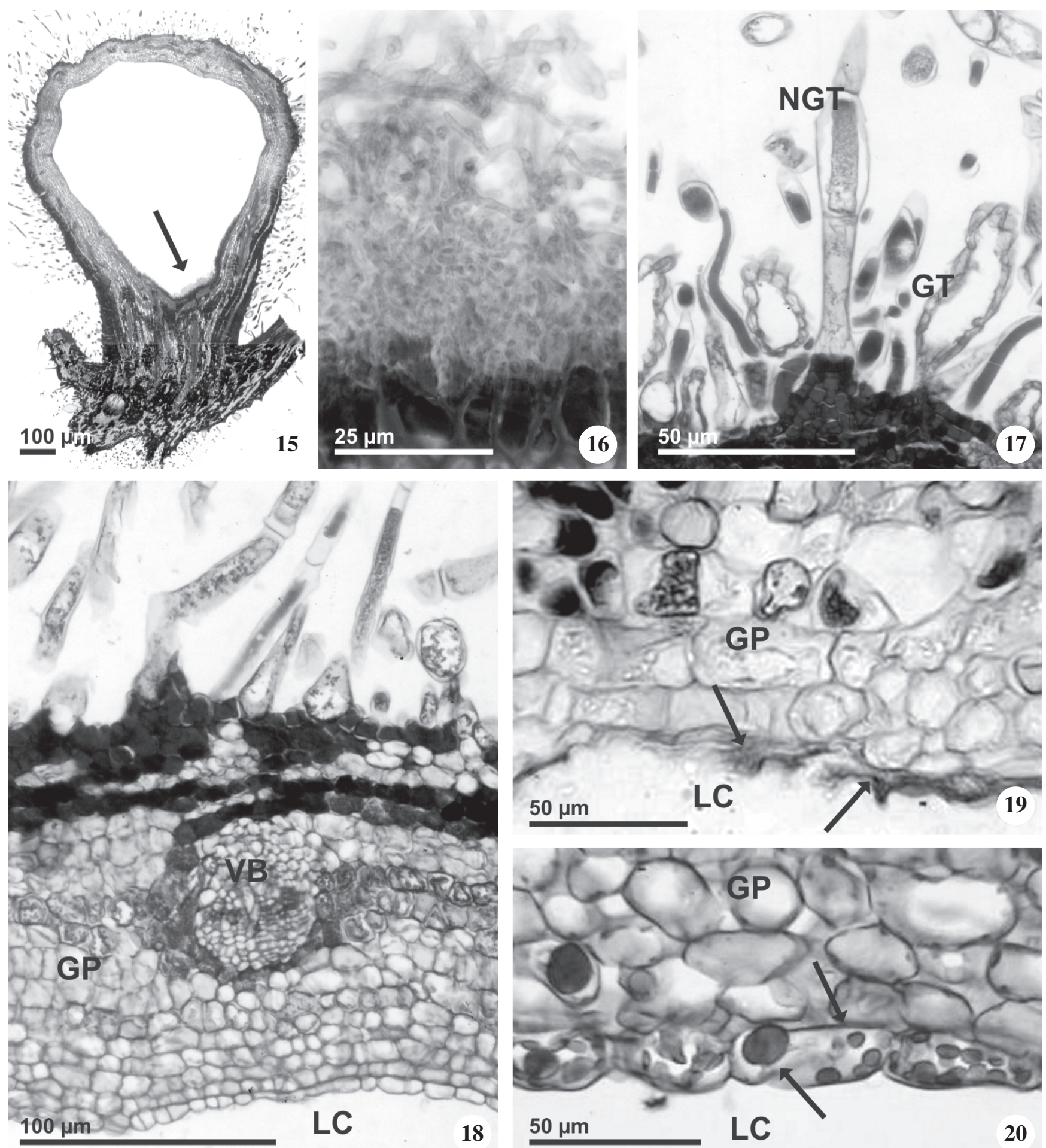

Figures 15-20. Schyzomyia macrocapillata gall in Bauhinia brevipes 15-20. Transverse sections. 15. Phase 5: general aspect with wide larval chamber with fungi hyphae (arrow). 16. Detail of fungi hyphae. 17. Detail of trichomes on gall surface. 18. Detail of gall wall with parenchymatic cells and a vascular bundle. 19-20. Phase 6: Detail of gall internal parenchyma. 19. Disrupted cells in the covering layer (arrows). 20. Parenchyma with phenolic contents in the cells of the covering layer. $(\mathrm{GP}=$ gall parenchyma; $\mathrm{GT}=$ glandular trichome; $\mathrm{LC}=$ larval chamber; $\mathrm{NGT}=$ non-glandular trichome; $\mathrm{VB}=$ vascular bundle) . 


\section{Discussion}

Schizomyia macrocapillata induces galls on young, unfolded leaves of Bauhinia brevipes, a common induction site for the Asphondyliini (Yukawa \& Rohfritsch 2005). The success of gall induction is strongly dependent on the presence of undifferentiated cells, perhaps because these cells may be more easily manipulated (Mani 1964), and may present low resistance to induction (see Fernandes 1998). Schizomyia macrocapillata galls on B. brevipes result from a small and localized tissue growth that develops into a pouch gall.

The ground system of $S$. macrocapillata galls was not photosynthetizing. The parenchyma of the galls did not differentiate into palisade and spongy layers, as described for insect galls induced on Chrysothamnus nauseosus subsp. hololeucus (A. Gray) H. M. Hall \& Clem. (Kraus et al. 2003) and Piptadenia gonoacantha (Arduin \& Kraus 1995), but rather constitute a neoformed gall parenchyma with round cells with poor developed intercellular spaces, similarly to galls induced by Cecidomyiidae on Guarea macrophylla subsp. tuberculata (Kraus et al. 1996). The anatomical pattern of galls induced on $B$. brevipes corroborates the findings of Rohfritsch (1992) who states that tissues of pouch galls are less differentiated than those of covering galls.

Notably, gall vascular bundles were predominantly phloematic, as observed in galls induced by the gall midge Izeniola obesula on Suaeda monoica Forssk. ex J. F. Gmel. (Dorchin et al. 2002). Moreover, galls induced by $S$. macrocapillata lack secondary xylem cells and periciclic fibers. The non differentiation of these lignified cells was also observed in the ambrosia galls induced by an unidentified species of Cecidomyiidae on leaves of Baccharis concinna (Arduin \& Kraus 2001), and may indicate that the energy otherwise used to differentiate lignified cells is deviated to other gall requirements. Indeed, the exclusively phloematic bundles indicate the establishment of a drain of photosynthates to gall tissues (Rohfritsch 1992). The predominant phloematic bundles developed in S. macrocapillata galls on B. brevipes was also reported for other galls (Arduin et al. 1991, 2005, Arduin and Kraus 1995, Kraus et al. 2002) and may play an important role in nutrient supply of the growing gall at the expense of other plant tissue (Vandevyvere \& de Bruyn 1998). The structure of ambrosia galls is generally simple, with few tissue modifications when compared to non fungal-associated galls (Rohfritsch 2008).

Several anatomical features account for the defense of the galling larvae against natural enemies. First, the sclerenchyma layer is assumed to function as a protective mechanism against parasitoids, providing mechanical rigidity to gall tissues and preventing oviposition by microhymenopterans (Brooks \& Shorthouse 1998, Vandevyvere \& de Bruyn 1998). However, galls induced by $S$. macrocapillata lack this sclerenchyma layer around the larval chamber, and this is also true for pouch galls (Rohfritsch 1992). The modification of epidermal cells into long trichomes should provide an effective protection to the larvae against parasitoids. Furthermore, phenolic compounds have been shown to deter herbivore feeding (Abrahamson et al. 1991) and their occurrence in the external layers suggests the manipulation of host plant potentialities by the inhabiting larvae towards a decrease in the impacts of natural enemies (Hartley 1998, Nyman and Julkunen-Titto 2001). Finally, protection provided by fungi hyphae (Taper \& Case 1987) should not take place in the case of $S$. macrocapillata due to poor hyphae development (Dorchin et al. 2002). In S. macrocapillata, the induced mechanism termed hypersensitive reaction accounts for more than $90 \%$ of larvae mortality, leaving few galls to be attacked by natural enemies (Santos $e t$ al. 2008).

The presence of fungi hyphae in the larval chamber, and the fact that the gall inducing insect belongs to Schizomyia (a genus that commonly induce ambrosia galls; Bronner 1992, Gagné 1994, Rohfritsch 2008) confirms that this gall can be classified as an ambrosia gall. Hyphae were found in the first developmental phases, as was observed in the ambrosia galls induced by Izeniola obesula and Stefaniola defoliata (Cecidomyiidae) on Suaeda monoica shoots (Dorchin et al. 2002) and for Schizomyia galiorum galls induced in Galium mollugo L. (Rohfritsch 2008). There are reports on the role of fungi in influencing gall initiation and morphogenesis (Dorchin et al. 2002, Stone and Schönrogge 2003), which apply here. In ambrosia galls the fungus is not easily detected during the early stages of gall development. In some areas, the fungus is so transparent that the larva appears to be feeding on plant tissue rather than on the mycelium (Rohfritsch 2008). In Asphondyliini galls, the fungus remains on the surface of the attacked organ, occasionally developing short hyphae. But since the fungus has access to the vascular tissue of the host plant, it is responsible for gall growth and shape, and is therefore essential in gall growth induction and development (Rohfritsch 2008).

The feeding action of the larvae inside the gall was inconclusive but strongly suggests mycetophagy. Cell contents of the covering layer reacted positively for phenolic contents and presented dense cytoplasm (data not shown), contrasting to the general pattern proposed 
for ambrosia galls (Bronner 1992). However, fungi hyphae were in direct contact to the covering layer as described for ambrosia galls induced on B. dracunculifolia DC. and B. concinna (Arduin \& Kraus 2001). At the last phase, the senescence, the covering layer cells present phenolic contents (data not show), similarly to a gall induced by an undescribed Cecidomyiidae species on Tabebuia ochracea (Cham.) Standl. (Bignoniaceae) (Scareli-Santos $\&$ Varanda 2003). This indicates the end of the feeding activity of the galling herbivore as shown in several gall systems.

In contact to the small cells of the covering layer in the $S$. macrocapillata-B. brevipes system, a compact layer of fungi hyphae is common. This is a common feature of ambrosia galls induced by species of the Asphondyliini (Bissett \& Borkent 1988). The development of the fungi within the larval chamber and the presence of phenolics in the covering layer only at senescent phase suggests that the larva uses the mycelia and the covering layer cells simultaneously as food resources (Dorchin et al. 2002). This is likely to happen since the larva in fungal-associated galls feed upon a structure composed of plant cells and protein-rich fungal cells, which explains the absence of the classical nutritive tissue (Rohfritsch 2008). If the larvae feed only on mycelia, a major development of the fungi should be expected, which was not observed.

In $S$. macrocapillata galls, a phase of tissue rearrangement was detected just after initiation, performing six phases of gall development. These ontogenetical phases contrasted to the model proposed by Rohfritsch (1992) for Cecidomyiidae galls, which is restricted to four phases. During the phase of maturation, gall tissues were completely differentiated, and invagination spots towards gall chamber were observed. The final expansion of gall structure takes place in the growth phase, probably due to homogenization of the hypertrophied process in distinct cell layers.

Acknowledgments - We thank T.G. Cornelissen and two anonymous reviewers for suggestions on earlier versions of the manuscript. Estação Ecológica de Pirapitinga - Ibama provided logistical support. This study was supported by CNPq (472491/2003-2304851/2004-3, 140071/2003-2).

\section{References}

ABRAHAMSON, W.G., MCCREA, K.D., WHITWELL, A.J. \& VERNIERI, L.A. 1991. The role of phenolics in goldenrod ball gall resistance. Biochemical Systematics and Ecology 19:615-622.
ARDUIN, M., FERNANDES, G.W. \& KRAUS, J.E. 2005. Morphogenesis of gall induced by Baccharopelma dracundulifoliae (Hemiptera: Psyllidae) on Baccharis dracunculifolia (Asteraceae) leaves. Brazilian Journal of Biology 65:559-571.

ARDUIN, M. \& KRAUS, J.E. 1995. Anatomia e ontogenia de galhas foliares de Piptadenia gonoacantha (Fabales, Mimosaceae). Boletim de Botânica da Universidade de São Paulo 14:109-130.

ARDUIN, M. \& KRAUS, J.E. 2001. Anatomia de galhas de ambrosia em folhas de Baccharis concinna e Baccharis dracunculifolia (Asteraceae). Revista Brasileira de Botânica 24:63-72.

ARDUIN, M., KRAUS, J.E. \& VENTURELLI, M. 1991. Estudo morfológico de galha achatada em folha de Struthanthus vulgaris Mart. (Loranthaceae). Revista Brasileira de Botânica 14:147-156.

AZEVEDO, L.G., BARBOSA, A.A.A., OLIVEIRA, A.L.C., GORGONIO, A.S., BEDRETCHUK, A.C., SIQUEIRA, F.B., RIZZO, H.G., SILVA, I.S., MOURA, L.C., ARAÚJOFILHO, M. \& SANTOS, R.V. 1987. Ensaio metodológico de identificação e avaliação de unidades ambientais: a Estação Ecológica de Pirapitinga-MG. Embrapa-CPAC, Brasília.

BISSET, J. \& BORKENT, A. 1988. Ambrosia galls: the significance of fungal nutrition in the evolution of the Cecidomyiidae (Diptera). In Coevolution of fungi with plants and animals. (K.A. Pirozynski \& D.L. Hawksworth, eds.) Academic Press, London, p.203-205.

BRONNER, R. 1992. The role of nutritive cells in the nutrition of cynipids and cecidomyiids. In Biology of insect-induced galls (J.D. Shorthouse \& O. Rohfritsch, eds.). Oxford University Press, Oxford, p.118-140.

BROOKS, S.E. \& SHORTHOUSE, J.D. 1998. Developmental morphology of stem galls of Diplolepis nodulosa (Hymenoptera: Cynipidae) and those modified by the inquiline Periclistus pirata (Hymenoptera: Cynipidae) on the stems of Rosa blanda (Rosaceae). Canadian Journal of Botany 76:365-381.

CORNELISSEN, T.G. \& FERNANDES, G.W. 2001. Patterns of attack by herbivores on the tropical shrub Bauhinia brevipes (Leguminosae): vigor or chance? European Journal of Entomology 98:37-40.

CORNELISSEN, T.G., MADEIRA, B.G., ALLAIN, L.R., LARA, A.C.F., ARAÚJO, L.M. \& FERNANDES, G.W. 1997. Multiple responses of insect herbivores to plant vigor. Ciência e Cultura 49:285-288.

DORCHIN, N., FREIDBERG, A. \& ALONI, R. 2002. Morphogenesis of stem gall tissues induced by larvae of two cecidomyiid species (Diptera: Cecidomyiidae) on Suaeda monoica (Chenopodiaceae). Canadian Journal of Botany 80:1141-1155.

FERNANDES, G.W. 1998. Hypersensitivity as a phenotypic basis of plant induced resistance against a galling insect (Diptera: Cecidomyiidae). Environmental Entomology 27:260-267. 
FONTES, E.M.G., HABECK, D.H. \& SLANSKY Jr., F. 1994. Phytophagous insects associated with goldenrods (Solidago spp.) in Gainesville, Florida. Florida Entomologist 77:209-221.

GAGNÉ, R.J. 1989. The plant-feeding midges of North America. Comstock, Ithaca.

GAGNÉ, R.J. 1994. The gall midges of the neotropical region. Comstock, Ithaca.

GONÇALVES-ALVIM, S.J. \& FERNANDES, G.W. 2001. Biodiversity of galling insects: historical, community and habitat effects in the neotropical savannas. Biodiversity and Conservation 10:79-98.

HARTLEY, S.E. 1998. The chemical composition of plant galls: are levels of nutrients and secondary compounds controlled by the gall-former? Oecologia 113:492-501.

JOHANSEN, D.A. 1940. Plant microtechnique. McGrawHill Book, New York.

KRAUS, J.E. \& ARDUIN, M. 1997. Manual básico de métodos em morfologia vegetal. Universidade Federal Rural do Rio de Janeiro, Rio de Janeiro.

KRAUS, J.E., ARDUIN, M. \& VENTURELLI, M. 2002. Anatomy and ontogenesis of hymenopteran leaf galls of Struthanthus vulgaris Mart. (Loranthaceae). Revista Brasileira de Botânica 25:449-458.

KRAUS, J.E., ISAIAS, R.M.S., VECCHI, C. \& FERNANDES, G.W. 2003. Structure of insect galls on two sympatric subspecies of Chrysothamnus nauseosus (Pall. ex Pursh) Britton (Asteraceae). Boletim de Botânica da Universidade de São Paulo 21:251-263.

KRAUS, J.E., SUGIURA, H.C. \& CUTRUPI, S. 1996. Morfologia e ontogenia em galhas entomógenas de Guarea macrophylla subsp. tuberculata (Meliaceae). Fitopatologia Brasileira 21:349-356.

MAIA, V.C. \& FERNANDES, G.W. 2005. Two new species of Asphondyliini (Diptera: Cecidomyiidae) associated with Bauhinia brevipes (Fabaceae). Zootaxa 1091:27-40.

MANI, M.S. 1964. Ecology of plant galls. Dr. Junk Publisher, The Hague.

MEYER, J. 1987. Plant galls and gall inducers. Gerbrüder Borntraeger, Berlin.
NYMAN, R. \& JULKUNEN-TITTO, R. 2001. Manipulation of the phenolic chemistry of willows by gall-inducing sawflies. Proceedings of the National Academy of Sciences 97:13184-13187.

ROHFRITSCH, O. 1992. Patterns in gall development. In Biology of insect-induced galls (J.D. Shorthouse \& O. Rohfritsch, eds.). Oxford University Press, Oxford, p.60-86.

ROHFRITSCH, O. 2008. Plants, gall midges, and fungi: a three-component system. Entomologia Experimentalis et Applicata 128:208-216.

SANTOS, J.C., SILVEIRA, F.A.O. \& FERNANDES, G.W. 2008. Long term oviposition preference and larval performance of Schizomyia macrocapillata (Diptera: Cecidomyiidae) on larger shoots of its host plant Bauhinia brevipes (Fabaceae). Evolutionary Ecology 22:123-137.

SCARELI-SANTOS, C. \& VARANDA, E.M. 2003. Morphological and histochemical study of leaf galls of Tabebuia ochracea (Cham.) Standl. (Bignoniaceae). Phytomorphology 53:207-214.

STONE, G.N., SCHÖNROGGE, K. 2003. The adaptive significance of insect gall morphology. Trends in Ecology and Evolution 18:512-522.

TAPER, M.L. \& CASE, T.J. 1987. Interactions between oak tannins and parasite community structure: unexpected benefits of tannins to cynipid gall-wasps. Oecologia. 71:254-261.

VANDEVYVERE, I. \& DE BRUYN, L. 1998. Morphological and histochemical analysis of galls of Lipara lucens (Diptera, Chloropidae) on Phragmites australis (Poaceae). Canadian Journal of Botany 76:1374-1384.

VAZ, A.M.S.F. \& TOZZI, A.M.G.A. 2003. Bauhinia ser. Cansenia (Leguminosae: Caesalpinioideae) no Brasil. Rodriguésia 54:55-143.

YUKAWA, J. \& ROHFRITSCH, O. 2005. Biology and ecology of gall-inducing Cecidomyiidae (Diptera). In Biology, ecology and evolution of gall-inducing arthropods (A. Raman, C.W. Schaefer \& T.M. Withers, eds.). Science Publishers, Enfield, p.277-319. 